\title{
In vitro antimicrobial activity of Douro wines against clinical helicobacter pylori strains
}

\author{
Actividad antimicrobiana in vitro de los vinos del Duero sobre cepas clínicas \\ de helicobacter pylori
}

Lidia Po Catalao Dionisio ${ }^{1}$, Alejandro Manuel Labella², María Palma ${ }^{3}$, Juan José Borrego ${ }^{4}$

\section{Abstract}

Aim. In vitro antimicrobial activities of seven wines (5 reds and 2 whites) from the Douro region (Iberian Peninsule) against eleven clinical strains of Helicobacter pylori were evaluated. Methods. The disk diffusion method, using Columbia Agar supplemented with horse blood $(\mathrm{CAB})$, were used to determine the antimicrobial properties of some wine components against $H$. pylori strains. Potential interactions of antioxidants contained in the wines and two antimicrobials (amoxicillin and metronidazole) were studied by the disk diffusion method. Results. All the tested strains showed growth in CAB supplemented with $9 \%$ of the tested wines but none of them grew in media supplemented with $45 \%$ and $67.5 \%$ of wine. Similarly, all the tested strains grew in media with the concentration of proanthocyanidins present in the different types of the studied wines. The Minimal Inhibitory Concentration (MIC) values of the wine antioxidant components tested (benzoic acid, catechin, quercetin, and resveratrol) indicate that resveratrol was the most powerful inhibitory substance against $H$. pylori. An effect of potentiation between amoxicillin and metronidazole and the antioxidants tested was also established. The interaction of amoxicillin and resveratrol or metronidazole and catechin increased the antimicrobial activity against H. pylori. Conclusions. The results obtained suggested a potential role of resveratrol as a chemopreventive agent for $H$. pylori infection.

Keywords: helicobacter pylori, antioxidants, antimicrobial activity, Duero wine, resveratrol, proanthocyanidins.

\footnotetext{
1. PhD in Biology. MED-Mediterranean Institute for Agriculture, Environment and Development. Pólo do Algarve. Campus de Gambelas 8005, 139-Faro, Portugal. ORCID: 0000-0002-0530-9395.

2. $\mathrm{PhD}$ in Microbiology. Department of Microbiology, University of Malaga, Campus Universitario Teatinos, 29071-Malaga, Spain. ORCID: 0000-0001-9446-6458.

3. PhD in Food Consumption and Nutrition. Escola Superior de Saúde da Universidade do Algarve, Campus de Gambelas 8005 139-Faro, Portugal.

ORCID 0000-0002-9278-5540

4. PhD in Microbiology. Department of Microbiology, University of Malaga, Campus Universitario Teatinos, 29071-Malaga, Spain. ORCID: 0000-0002-2174-0652.
} 


\section{Resumen}

Objetivo. Se evaluó las actividades antimicrobianas in vitro de siete vinos (5 tintos y 2 blancos) de la región del Duero (Peninsula Ibérica) frente a once cepas de Helicobacter pylori de origen clínico. Métodos. Para determinar las propiedades antimicrobianas de algunos componentes del vino sobre las cepas de $H$. pylori se utilizaron las técnicas de difusión en disco en placas de agar Columbia suplementado con sangre de caballo (CAB). La potential interacción entre las sustancias antioxidantes presentes en los vinos y dos antimicrobianos (amoxicilina y metronidazol) se determinó usando la técnica de difusión en disco. Resultados. Todas las cepas ensayadas mostraron crecimiento en CAB suplementado con el 9\% de los vinos analizados, pero no se obtuvo crecimiento de ninguna de las cepas en medios suplementados con el $45 \%$ y el $67,5 \%$ de vino. Asimismo, todas las cepas ensayadas crecieron en medios con la concentración de proantocianidinas presentes en los diferentes tipos de vinos estudiados. Los valores de concentración mínima inhibitoria (CMI) de los componentes antioxidantes de los vinos ensayados (ácido benzoico, catequina, quercetina y resveratrol) indican que el resveratrol fue la sustancia más potente en la inhibición del crecimiento de $H$. pylori. También se estableció un efecto de potenciación entre amoxicilina y metronidazol y los antioxidantes ensayados. Las interacciones amoxicilina + resveratrol y metronidazol + catequina aumentaron la actividad antimicrobiana contra $H$. pylori. Conclusiones. Los resultados obtenidos sugieren un papel potencial del resveratrol como agente quimiopreventivo de la infección por $H$. pylori.

Palabras claves: helicobacter pylori, antioxidantes, actividad antimicrobiana, vinos del Duero, resveratrol, proantocianidinas.

\section{Introduction}

Helicobacter pylori is accepted to be the causative agent of acute and chronic gastritis, and a major predisposing factor for peptic ulcer disease, gastric carcinoma, gastric lymphoma and mucosa-associated lymphoid tissue (MALT) $(1,2)$. This microorganism is a spiral-shaped Gram-negative bacterium endowed with a very powerful urease activity and with polar flagella. Urease activity buffers the $\mathrm{pH}$ at the cell surface, allowing bacterial survival in the stomach lumen until it enters the mucus layer by means of their flagella, which is a protective barrier against the high proton concentration (3). To colonize the host stomach, H. pylori expresses several virulence factors that can play a role in pathogenesis, being the most important the vacuolating VacA, a cytotoxin associated with gene A ( CagA), the neutrophil-activating protein (NAP), and the urease activity (4). 
Peptic ulcer disease and other $H$. pylori-associated disorders usually regress or even heal completely after treatment with antimicrobials. The most effective and best tolerated combinations consist of a triple therapy which includes bismuth salts or proton pump inhibitors with two antibiotics (clarithromycin and amoxicillin, clarithromycin and metronidazole, or amoxicillin and metronidazole), and a quadruple therapy, including a proton pump inhibitor plus a bismuth salt and the antibiotics metronidazole and tetracycline $(5,6)$. However, the available antimicrobial therapies for $H$. pylori infection have several shortcomings: (i) limited efficacy in vivo of the antimicrobials due to both inability of drugs to achieve appropriate levels in the gastric mucus layer, and/or inactivation of drugs at low $\mathrm{pH}$ (7); and (ii) the development of antimicrobial resistance for $H$. pylori (8-10). Consequently, an optimal therapy against $H$. pylori infection is not available yet, therefore, novel approaches are needed, including vaccine development (11), use of antimicrobial peptides (12), and utilization of naturally occurring compounds with antimicrobial activity, such as porphyrins, essential oils and plant polyphenols (13-15).

Several epidemiological studies have demonstrated that the modest consumption of alcoholic drinks may influence spontaneous eradication of $H$. pylori $(16,17)$. Alcoholic beverages, mainly wine, have a strong antimicrobial activity, as has been shown both in vitro and in vivo $(18,19)$; however, other conditions depending on the beverage type, dose, host physiological conditions, to name a few, affect to the $H$. pylori mechanisms of action and may explain the inconsistent results obtained by several authors $(19,20)$. Marimon et al (21) carried out an in vitro analysis of the bactericidal action of red wine, $\mathrm{HCl}$ solution ( $\mathrm{pH} 3.5$ ), a solution containing $12 \%$ ethanol, and $12 \%$ ethanol at $\mathrm{pH} 3.5$ on $H$. pylori. Red wine exerted a higher bactericidal effect upon $H$. pylori than that other observed for the other solutions. However, no explanation was found for the mechanisms by which wine exerts an in vitro bactericidal effect independently of its alcohol concentration, nor have the substances responsible been identified to date.

In the present study, the antibacterial effect of different wines from the Douro region (Iberian Peninsule) and their main components (proanthocyanidins, pH, alcohol content and four antioxidant compounds) on $H$. pylori strains (isolated from gastric biopsies) has been evaluated. In addition, the potential interactions between amoxicillin or metronidazole and the antioxidant components of the wine have also been evaluated.

\section{Materials and methods}

\section{Bacterial strains, culture and identification}

Eleven clinical strains of $H$. pylori isolated from gastric biopsies and a reference stra- 
in (CCUG 15813) from the Culture Collection of the University of Gothenburg (Sweden) have been used in this study. Strains were subcultured on Columbia Agar (Oxoid, Hampshire, UK) supplemented with $10 \%$ of defibrinated horse blood (Oxoid) (CAB) and in $\mathrm{CAB}$ with Dent's supplement (SR 147, Oxoid). Subcultures were incubated at $36 \pm 1{ }^{\circ} \mathrm{C}$ under microaerophilic conditions using jars with Gas generating kits for Campylobacter (Oxoid) for 48-72 h (22). All isolates were identified as $H$. pylori using the phenotypic and biochemical tests described previously (23). The urease activity was performed using Urea Broth Medium (Oxoid) with the SR20 20K supplement (Oxoid).

\section{Antibiotic susceptibility assays and PCR-based genotyping}

Disk diffusion testing was performed by standard CLSI methods (24) using CBA for the evaluation in vitro of the antibiotic susceptibility of $H$. pylori strains against the following antimicrobials, used frequently for treatment of $H$. pylori infection, supplied by Oxoid: metronidazole, clarithromycin, erythromycin, amoxicillin, ciprofloxacin, moxifloxacin, levofloxacin, rifabutin, furazolidone, and tetracycline. Inocula were prepared from two agar plates of a 2-day fresh growth on CBA, which were scraped and suspended in $5 \mathrm{ml}$ of Columbia broth (CB) (Oxoid) to achieve the turbidity equivalent to a McFarland standard of 3 to 4 . Serial dilutions of the bacterial suspensions were performed to yield a colony count of about 4 x $108 \mathrm{CFU} / \mathrm{mL}$. After incubation period $(48-72 \mathrm{~h})$ at $36 \pm 1^{\circ} \mathrm{C}$ under a microaerophilic atmosphere, inhibition zone diameters (in $\mathrm{mm}$ ) were read with the aid of callipers. Bacterial isolates were classified as resistant, sensitive or intermediate according to the National Committee for Clinical Laboratory Standards breakpoints (25). Genomic DNA of $\mathrm{H}$. pylori isolates was extracted as described by Oleastro et al (26). Genotyping of the virulence factors vacuolating gene (vacA) and cytotoxin-associated gene (cagA) was performed by PCR in accordance to protocols and primers described previously $(27,28)$.

\section{Determination of the Minimal Inhibitory Concentrations (MICs)}

E-test strips supplied by AB Biodisk (Solna, Sweden) were used to determine the MICs of amoxicillin and metronidazole. CBA plates were allowed to dry for $10 \mathrm{~min}$ and the strips were kept on the bench for 10 15 min to attain room temperature. Colonies from pure cultures of $H$. pylori were transferred using a sterile loop into a sterile tube containing $4.5 \mathrm{ml}$ of $\mathrm{CB}$ and adjusted to standard 2 of the MacFarland scale. The solution was flooded over the plate (CBA) and excess fluid was removed with a pipette. After drying for 15-20 min, an E-test strip was placed on each plate and then incubated under microaerophilic conditions at $36 \pm 1{ }^{\circ} \mathrm{C}$ for $48-72 \mathrm{~h}$. Results from E-test were interpreted by recording the point of 
intersection of the growth elliptic margin zone with the MIC scale value on the E-test strip. MIC breakpoints of $>2 \mu \mathrm{g} / \mathrm{ml}$ and $>8$ $\mu \mathrm{g} / \mathrm{ml}$ were used for amoxicillin and metronidazole, respectively.

\section{Susceptibility assays of the wines and their components}

Seven different wines of Douro region, 5 reds and 2 whites, were used to determine the susceptibility of $H$. pylori strains. Four red wines were product of monocastes each one named Touriga Nacional, Touriga Brasileira, Tinta Roiz, and Tinta Barroca. The fifth one was a mixture of castes Negra mole, Castelao and Trincadeira. The wines were previously filtered through membrane filters of $0.45-\mu \mathrm{m}$ pore-size (Millipore Co., Belford, MA, USA), and several concentrations of each filtered wine were added to culture media in aseptic conditions. Four different assay media were prepared; all of them were composed of $39 \mathrm{~g} / \mathrm{L}$ of $\mathrm{CAB}$ and variable percentages of filtered wine $(9 \%$ for medium 1, 22.5\% for medium 2, 45\% for medium 3, and $67.5 \%$ for medium 4 ).

To control the effect of alcohol graduation in the growth of $\mathrm{H}$. pylori, several compositions of $\mathrm{CAB}$ supplemented with ethanol were performed. The final proportion of alcohol in media tested were $12.69^{\circ}(\mathrm{v} / \mathrm{v})$, $13^{\circ}(\mathrm{v} / \mathrm{v}), 14.55^{\circ}(\mathrm{v} / \mathrm{v})$ and $14.8^{\circ}(\mathrm{v} / \mathrm{v})$. In addition, $\mathrm{H}$. pylori was grown in $\mathrm{CAB}$ plates at low $\mathrm{pH}$ values (from 4.49 to 4.89 ) by adding of lactic acid (10\%).
Proanthocyanidins were isolated from several red wine grapes originating from the Douro region. The pips were carefully removed from 150 frozen grapes and then lyophilized. The dry extract was stored at $-20^{\circ} \mathrm{C}$ until use. Proanthocyanidins of the extract were separated and identified by HPLC following the protocol described by Roggero et al (29). The detection of proanthocyanidins was performed by the monitorization of the absorbance detected at $535 \mathrm{~nm}$ in a DAD (Merck, Madrid, Spain). The proanthocyanidin concentrations were calculated attending to the calibration line obtained by the use of maldivin as pattern. Different concentrations of proanthocyanidins in distilled water according to the values of HPLC of the tested wines $(0.93$ $\mathrm{g} / \mathrm{L}$ for Touriga Nacional, $0.63 \mathrm{~g} / \mathrm{L}$ for Tinta Barroca, $0.50 \mathrm{~g} / \mathrm{L}$ for Tinta Roriz, and $0.34 \mathrm{~g} / \mathrm{L}$ for Touriga Brasileira) were added to the $\mathrm{CAB}$ to achieve a concentration of $67.5 \%(\mathrm{v} / \mathrm{v})$. Inoculated plates were incubated at $36 \pm 1^{\circ} \mathrm{C}$ under a microaerophilic atmosphere for $72 \mathrm{~h}$.

Considering the total phenol index as the equivalent to gallic acid units calculated by the Folin-Cicocalten's method. The total phenolic compounds of the wines were determined by the absorbance values at $725 \mathrm{~nm}$ of different concentrations of gallic acid. The agar dilution method (30) was used to determine the MICs of the antioxidant compounds present in the wines. The antioxidants used were benzoic acid (Sigma-Aldrich Química, S.A., Madrid, Spain), catechin (Sigma-Aldrich), quercetin 
(Sigma-Aldrich) and resveratrol (Sigma-Aldrich), and they were prepared in deionised water. Media consisted of CBA with the antioxidant compounds tested at concentrations of 0.01 to $0.1 \mathrm{mg} / \mathrm{mL}$ in doubling dilutions. Inocula of $10 \mu \mathrm{L}$ of bacterial suspension of each $H$. pylori strain (about $4 \mathrm{x}$ $10^{8} \mathrm{CFU} / \mathrm{mL}$ ) were applied on the surface of the growth medium. Plates were incubated at $36 \pm 1^{\circ} \mathrm{C}$ under a microaerophilic atmosphere for $72 \mathrm{~h}$. The lowest concentration of antioxidant compound showing no growth was recorded as the MIC. All the susceptibility assays were three-times replicated.

To determine the possible interaction between amoxicillin and/or metronidazole and the wine antioxidants, $10 \mu \mathrm{g}$ of each antioxidant agent tested was added to each aqueous antibiotic solution containing amoxicillin $(25 \mu \mathrm{g})$ or metronidazole (5 $\mu \mathrm{g})$. Later, the antibiotic solutions supplemented with the antioxidants were tested according to the broth microdilution method (25). A t-student test was applied to determine the statistical differences of the susceptibility of the bacterial strains to the antimicrobials and to the interactions antimicrobial-antioxidant agents.

\section{Results}

\section{Characterization of the H. pylori strains}

All the isolates collected from endoscopic biopsies were confirmed as $H$. pylori according to 23 phenotypic features tested specified by Megrauf and Lee (23) (data not shown). The molecular characterization of the H. pylori isolates using a PCR-based method allowed the discrimination of the isolates in three groups on the basis of the presence/absence of the virulence factors CagA and VacA (Table 1). Group 1 (Cag A $+/$ Vac A s $1 / \mathrm{m} 1$, urease + ) composed to 7 strains; group 2 (Cag $\mathrm{A}+/ \mathrm{Vac} \mathrm{A} s 1 / \mathrm{m} 2$, urease +), 3 strains; group 3 (Cag A -/Vac A s $2 / \mathrm{m} 2$, urease +$), 2$ strains. Overall, ten strains $(83.3 \%)$ presented the cytotoxin CagA, whereas all the strains showed the vacuolating factor VacA and the urease activity (Table 1). Antibiotic susceptibility of $H$. pylori showed that all the strains were susceptible to 10 antimicrobials tested, but only 4 strains were resistant to the concentration tested $(50 \mu \mathrm{g})$ of metronidazole $(\mathrm{Ta}$ ble 1).

Table 1. Distribution of Helicobacter pylori genotypes and antibiotic susceptibility using the disk diffusion method.

\begin{tabular}{|l|l|l|l|l|l|l|l|l|l|l|l|}
\hline Strains & Genotypes & Me & C & E & AMO & CP & MO & LE & Rf & F & Te \\
\hline E2 & Cag A +/Vac A s $1 / \mathrm{m} 2$ & Sa & S & S & S & S & S & S & S & S & S \\
\hline E4 & Cag A +/Vac A s $1 / \mathrm{m} 1$ & S & S & S & S & S & S & S & S & S & S \\
\hline E8 & Cag A +/Vac A s $1 / \mathrm{m} 2$ & S & S & S & S & S & S & S & S & S & S \\
\hline E9 & Cag A / Vac A s2/m2 & Rb & S & S & S & S & S & S & S & S & S \\
\hline
\end{tabular}




\begin{tabular}{|l|l|l|l|l|l|l|l|l|l|l|l|}
\hline Strains & Genotypes & Me & C & E & AMO & Cp & MO & LE & Rf & F & Te \\
\hline E10 & Cag A +/Vac A s $1 / \mathrm{m} 1$ & R & S & S & S & S & S & S & S & S & S \\
\hline E28 & Cag A +/Vac A s $1 / \mathrm{m} 1$ & S & S & S & S & S & S & S & S & S & S \\
\hline E120 & Cag A +/Vac A s $1 / \mathrm{m} 1$ & S & S & S & S & S & S & S & S & S & S \\
\hline E123 & Cag A -/Vac A s2/m2 & S & S & S & S & S & S & S & S & S & S \\
\hline E126 & Cag A +/Vac A s $1 / \mathrm{m} 2$ & R & S & S & S & S & S & S & S & S & S \\
\hline E128 & Cag A +/Vac A s $1 / \mathrm{m} 1$ & R & S & S & S & S & S & S & S & S & S \\
\hline E149 & Cag A + Vac A s $1 / \mathrm{m} 1$ & S & S & S & S & S & S & S & S & S & S \\
\hline CCUG & Cag A +/Vac A s $1 / \mathrm{m} 1$ & S & S & S & S & S & S & S & S & S & S \\
\hline
\end{tabular}

Me: metronidazole; C: clarithromycin; E: erythromycin; AMO: amoxicllin; Cp: ciprofloxacin;

MO: moxifloxacin; LE: levofloxacin; Rf: rifatubin; F: furazolide; Te: tetracycline.

${ }^{\mathrm{a} S}$ : sensitivity; ${ }^{\mathrm{b}} \mathrm{R}$ : resistance

Source: Authors.

Effect of the types and concentrations of wine, $\mathrm{pH}$, alcohol concentration and proanthocyanidins on $H$. pylori strains

All strains tested showed growth in medium 1 composed of $\mathrm{CAB}$ supplemented with $9 \%$ of all the wines assayed. On the contrary, none of the strains grew in media 3 and 4 ( $45 \%$ and $67.5 \%$ of wine, respectively). In the case of the medium 2, variable results were obtained depending on the type of wine tested, for example, only 7 strains (E2, E4, E8, E28, E123, E126 and E149) showed growth at $22.5 \%$ of Siria white wine, and 3 strains (E120, E128 and CCUG 15813) grew at $22.5 \%$ of Negra-Castalao red wine.

All $H$. pylori strains tested grew in media without wine at $\mathrm{pH}$ values ranging 4.49 to 4.89. Similarly, all the strains showed an optimal growth at the ethanol concentrations tested $\left(12.69^{\circ}, 13^{\circ}, 14.55^{\circ}\right.$ and $14.8^{\circ}$ $\mathrm{v} / \mathrm{v})$.
Similarly, all the $H$. pylori strains showed growth in CAB supplemented with the concentration of proanthocyanidins present in the different types of wines (Table 2). Urease test was used to study the changes of $H$. pylori strains after growth with wine (9\%) and proanthocyanidins (Table 2). Only the strain E126 loss the urease activity after grown in $\mathrm{CAB}$ supplemented with wine or proanthocyanidins; on the contrary, E8 and E128 strains maintained their urease activity for all the conditions assayed. An inverse but significant relationship was obtained between the response of the urease activity and the total phenol index of the red wine tested $[y=-48 x+33, r 2=0.914$, $\mathrm{p}<0.001$, where $\mathrm{y}$ is the absorbance at 750 $\mathrm{nm}$ and $\mathrm{x}$ is the concentration $(\mathrm{mg} / \mathrm{mL})$ of gallic acid]. 
Table 2. Response of the urease test of the Helicobacter pylori strains growth in CBA supplemented with 9\% red wine and proanthocyanidins (TPT).

\begin{tabular}{|l|l|l|l|l|l|l|l|l|l|l|l|l|}
\hline Wine type & E2 & E4 & E8 & E9 & E10 & E28 & E120 & E123 & E126 & E128 & E149 & CCUG \\
\hline T. Roriz & + & + & + & - & + & - & - & + & - & + & - & + \\
\hline TPТ $(0.5 \mathrm{~g} / \mathrm{L})$ & - & - & + & - & - & - & - & - & - & + & - & + \\
\hline T. Nacional & + & - & + & + & - & - & - & - & - & + & - & + \\
\hline TPТ $(0.93 \mathrm{~g} / \mathrm{L})$ & - & - & + & - & - & - & - & - & - & + & - & - \\
\hline T. Barroca & + & + & + & + & - & + & + & + & - & + & + & + \\
\hline TPТ $(0.63 \mathrm{~g} / \mathrm{L})$ & + & - & + & - & - & - & - & - & - & + & - & - \\
\hline T. Brasileira & + & - & + & + & - & + & - & - & - & + & - & + \\
\hline TPТ $(0.34 \mathrm{~g} / \mathrm{L})$ & + & - & + & - & - & + & - & - & - & + & - & - \\
\hline
\end{tabular}

Source: Authors.

\section{Effect of antioxidant agents on}

\section{H. pylori growth}

The inhibitory activity exerted by the antioxidant compounds tested on the $H$. pylo$r i$ growth depending both of the strain and the concentration of the antioxidants. The benzoic acid did not demonstrate to possess any effect on the tested strains at any assayed concentrations. On the contrary, the resveratrol showed the highest growth inhibition rates for all the tested strains, even at the lower concentration assayed $(0.1 \mathrm{mg} /$ $\mathrm{mL}$ ), and $91.7 \%$ of the strains possessed a (MIC) lower than $50 \mu \mathrm{g}$ (Table 3). On the other hand, only $33.3 \%$ of the tested strains presented a MIC lower than $50 \mu \mathrm{g}$ for quercetin, and $58.3 \%$ of them have MIC lower than $50 \mu \mathrm{g}$ for catechin (Table 3).

Table 3. MIC values $(\mu \mathrm{g} / \mathrm{mL})$ determined by the dilution agar test of several antioxidant compounds present in red wine on $H$. pylori strains.

\begin{tabular}{|c|c|c|c|c|c|c|c|c|c|c|c|c|}
\hline Antioxidants & E2 & E4 & E8 & E9 & E10 & E28 & E120 & E123 & E126 & E128 & E149 & CCUG \\
\hline Benzoic acid & $>100$ & $>100$ & $>100$ & $>100$ & $>100$ & $>100$ & $>100$ & $>100$ & $>100$ & $>100$ & $>100$ & $>100$ \\
\hline Catechin & $10-50$ & $>100$ & $10-50$ & $>100$ & $50-100$ & $10-50$ & $>100$ & $10-50$ & $10-50$ & $10-50$ & $>100$ & $10-50$ \\
\hline Quercetin & $>100$ & $>100$ & $>100$ & $>100$ & $10-50$ & $10-50$ & $>100$ & $>100$ & $>100$ & $<10$ & $>100$ & $10-50$ \\
\hline Resveratrol & $10-50$ & $<10$ & $10-50$ & $10-50$ & $10-50$ & $10-50$ & $<10$ & $<10$ & $<10$ & $10-50$ & $50-100$ & $<10$ \\
\hline
\end{tabular}

Source: Authors. 


\section{Interaction between antimicrobial agents and antioxidants tested}

Amoxicillin and metronidazole were choose to perform the interaction effects with antioxidant compounds on the basis of their susceptibility patterns on $H$. pylori strains tested (Table 1). Table 4 presents the results of potentiation or antagonism that produced the combination of antimicrobials and the antioxidant agents. The results obtained were very variable, depending both of the combination and the strains tested.

In the case of amoxicillin, resveratrol was the antioxidant that provoked a higher number of potentiation of the antimicrobial agent, since $50 \%$ of the $H$. pylori strains (E4, E8, E10, E120, E126 and CCUG) increased their susceptibility with the combination antimicrobial-antioxidant. However, two strains (E28 and E149) decrease their sensitivity with the combination compared to the effect of the antimicrobial alone. For metronidazole, the antibiotic-resistant strains E9, E10, E126 and E128 showed susceptibility to the antibiotic supplemented with catechin or benzoic acid. For the other strains tested, the combination metronidazole and antioxidant compounds only provoke potentiation effect in strains E120 and E123 with the combinations metronidazole-catechin, metronidazole-quercetin and metronidazole-resveratrol. On the contrary, in the strains E8, E28, E149 and CCUG an antagonism effect was recorded with all the combinations tested (Table 4).

Table 4. Interactions between antimicrobials and wine antioxidants on the susceptibility of $H$. pylori strains.

\begin{tabular}{|l|l|l|l|l|l|l|l|l|l|l|l|l|}
\hline Combinations & E2 & E4 & E8 & E9 & E10 & E28 & E120 & E123 & E126 & E128 & E149 & CCUG \\
\hline $\begin{array}{l}\text { Amoxicillin + } \\
\text { Benzoic acid }\end{array}$ & NS & P & NS & A & NS & NS & NS & NS & P & P & A & P \\
\hline $\begin{array}{l}\text { Amoxicillin }+ \\
\text { Catechin }\end{array}$ & NS & P & NS & A & NS & A & NS & NS & P & P & NS & P \\
\hline $\begin{array}{l}\text { Amoxicillin }+ \\
\text { Quercetin }\end{array}$ & NS & P & NS & A & NS & A & NS & P & P & NS & A & P \\
\hline $\begin{array}{l}\text { Amoxicillin }+ \\
\text { Resveratrol }\end{array}$ & NS & P & P & NS & P & A & P & NS & P & NS & A & P \\
\hline $\begin{array}{l}\text { Metronidazole }+ \\
\text { Benzoic acid }\end{array}$ & A & NS & A & P & NS & A & A & NS & NS & NS & A & A \\
\hline $\begin{array}{l}\text { Metronidazole + } \\
\text { Catechin }\end{array}$ & NS & NS & A & NS & P & A & P & P & P & P & A & A \\
\hline $\begin{array}{l}\text { Metronidazole }+ \\
\text { Quercetin }\end{array}$ & NS & NS & A & NS & NS & A & NS & P & NS & NS & A & A \\
\hline $\begin{array}{l}\text { Metronidazole + } \\
\text { Resveratrol }\end{array}$ & NS & NS & A & NS & NS & A & P & P & NS & NS & A & A \\
\hline
\end{tabular}

${ }^{a} \mathrm{NS}$ : No significant effect; ${ }^{\mathrm{b}} \mathrm{P}$ : Potentiation (significant at $\mathrm{p}<0.05$ level, t-student test);

cA: Antagonism (significant at $\mathrm{p}<0.05$ level, t-student test)

Source: Authors. 


\section{Discussion}

The frequent used of a limited number of antibiotics for anti- $H$. pylori therapy has resulted in the development of resistance mechanisms in $H$. pylori strains $(1,8,31)$. Therefore, it is necessary to study other approaches to control the $H$. pylori-related chronic inflammatory processes and mediators responsible for carcinogenesis. Phytoceuticals is a term for plant products that are active on biological systems. Some of them, present in red ginseng, green tea, or red wine, are known to inhibit $\mathrm{H}$. pylori colonization, decrease gastric inflammation by inhibiting cytokine and chemokine release, and repress precancerous changes by inhibiting nuclear factor-kappa B DNA binding, inducing profuse levels of apoptosis and inhibiting mutagenesis $(31,32)$.

The results obtained in the present study show that red wines from the Douro region, at concentration of $22.5 \%$, inhibited the in vitro growth of all the $H$. pylori strains tested. However, the two white wines tested allowed the growth of some $H$. pylori strains at this concentration (22.5\%) (data not shown). The inhibitory effect of wines on the growth of several enteropathogens, including to $H$. pylori, has been previously described (33-35). Marimon et al (21) demonstrated that red wine exerted a marked bactericidal effect upon $H$. pylori, and this effect could not be attributed to the acid $\mathrm{pH}$ of wine or at its alcohol concentration. Similar results have been obtained in our study, since none of the strains tested were inhibited by the four ethanol concentration tested (from $12.69^{\circ}$ to $14.8^{\circ} \mathrm{v} / \mathrm{v}$ ) and for the $\mathrm{pH}$ range (from 4.49 to 4.89 ). Our results suggested that the viability of the $H$. pylori strains grown in wine might depend on the antioxidant and other phenolic components of the wine. A relationship between the phenotypic characteristics and virulence factors of the strains might be established with the susceptibility to $22.5 \%$ of wine. However, no convincing explanation has yet been found for the mechanism by which wine exerts and in vitro bactericidal effect independently of its alcohol concentration. In vivo mechanisms that could contribute to the protective effect of wine might be the rise in acid secretion, and the increase in intestinal motility (18).

Polyphenols are plant secondary metabolites, which have. Wine, particularly red, contains a variety of polyphenols derived from the skin of the grape, including flavonols (quercetin), stylbenes (resveratrol), flavanols (catechin), gallic acid, condensed tannins (catechin polymers), and polymeric anthocyanins (36). These polyphenolic compounds potential health benefits on the human organism, mainly as antioxidants, anti-allergics, anti-inflammatories, anticarcinogenics, decrease platelet aggregation and endothelial adhesion, and decrease the level of high-density lipoprotein cholesterol (37-39). Several authors have demonstrated that the main active phenolic compound present in the red wine against $H$. pylori is the resveratrol $(33,40,41)$. Resveratrol 
exhibits a number of biological activities, including anti-inflammatory, antioxidant, platelet antiaggregatory and anticarcinogenic properties, and modulation of lipoprotein metabolism (42). The results obtained in the present study for resveratrol assays showed higher inhibitory effects on $H$. pylo$r i$ strains tested that those obtained for the other phenolic compounds tested, catechin and quercetin (Table 3). Similar results have been reported by Mahady et al (43), who obtained a MIC of $12.5 \mu \mathrm{g} / \mathrm{mL}$ (range of $6.25-25 \mu \mathrm{g} / \mathrm{mL}$ ) for $H$. pylori VacA and CagA +. However, in our study a no significant difference on the resveratrol effect on the sensitivity of $H$. pylori CagA + and CagA - strains was obtained. The mechanisms of action of resveratrol are very wide (44), and related to $H$. pylori, Tombola et al (15) suggested that this phenolic compound potently inhibit the VacA, a cytotoxin that plays an important role in the $H$. pylori colonization and survival in the stomach, and, in addition, it causes epithelial damage $(45,46)$.

H. pylori is susceptible to many antibiotics in vitro, although only a few of them can be used in vivo to treat the microbial infection. Several authors have suggested that several phytoceutical substances can be used either as monotherapy or in combination with antimicrobials $(8,12)$. In the present work, we have studied the potential interaction between two antimicrobials frequently used in the $H$. pylori therapy and the antioxidants present in red wine. The combination of amoxicillin with resveratrol showed the higher inhibitory effect; on the contrary, for metrodizadole only a significant effect was obtained in the resistant strains for the catechin. Similar potentiation effects between antioxidants and antibiotics have been reported previuosly (47, 48). However, alcoholic drinks cannot be consumed under metronidazole treatment because of a disulfiram-like reaction.

In short, the results obtained in this study demonstrate that red wine and resveratrol inhibit the growth of $H$. pylori strains in vitro and may support their role as chemopreventive agents of the bacterial infection or the insurgence in $H$. pylori infected individuals. However, due to the clinical guidelines for the treatment of dyspepsia recommend the stopping of ingestion of alcoholic beverages, further studies based on the effect of the ingestion of antioxidant substances, such as resveratrol, which has shown an inhibitory effect on in vitro growth of H. pylori strains, could be necessary for the development of clinical treatments using resveratrol as chemopreventive agent.

\section{Acknowledgements}

This study was partially supported by a grant from Foundation for Science and Technology and by FEDER through the Programme POCTI (POCTI/ESP/41217). We thank to Ana Vieira and Rui Pina for their helpful assistance in chemical analysis. 


\section{References}

1. Kusters JG, van Vliet AHM, Kuipers E. Pathogenesis of Helicobacter pylori infection. Clin $\mathrm{Mi}-$ crobiol Rev. 2006; 19:449-490. https://www. ncbi.nlm.nih.gov/pmc/articles/PMC1539101/ pdf/0054-05.pdf

2. Du MQ, Isaccson PG. Gastric MALT lymphoma: from aetiology to treatment. Lancet Oncol. 2002; 3:97-104. https://www.sciencedirect.com/science/ article/pii/S1470204502006514?via\%3Dihub

3. Sachs G, Weeks DL, Melchers K, Scott DR. The gastric biology of Helicobacter pylori. Annu Rev Physiol. 2003; 65:349-369. https://www.annualreviews.org/doi/pdf/10.1146/annurev.physiol.65.092101.142156

4. Dundon WG, de Bernard M, Montecucco C. Virulence factors of Helicobacter pylori. Int J Med Microbiol. 2001; 290:647-658. doi: 10.1016/s14384221(01)80002-3.

5. Laheij RJ, Rossum LG, Jansen JB, Straatman H, Verbeek AL. Evaluation of treatment regimens to cure Helicobacter pylori infection: a meta-analysis. Aliment Pharmacol Ther. 1999; 13:857-864. https://onlinelibrary.wiley.com/doi/epdf/10.1046/ j.1365-2036.1999.00542.x

6. Malfertheiner P, Mégraud F, O'Morain C, Hungin APS, Jones R, Axon A, et al. Current concepts in the management of Helicobacter pylori infection-the Maastricht 2-2000 Consensus Report. Aliment Pharmacol Ther. 2002; 16:167-180. https:// onlinelibrary.wiley.com/doi/epdf/10.1046/j.13652036.2002.01169.x

7. Debets-Ossenkopp YJ, Namavar F, MacLaren DM. Effect of an acidic environment on the susceptibility of Helicobacter pylori to trospectomycin and other antimicrobial agents. Eur J Clin Microbiol Infect Dis. 1995; 14:353-355. doi: 10.1007/ BF02116532.

8. Gerrits MM, van Vliet AHM, Kuipers E, Kusters JG. Helicobacter pylori and antimicrobial resistance: molecular mechanisms and clinical implications. The Lancet Infect Dis. 2006; 6:699-709. https://www.sciencedirect.com/science/article/pii/ S1473309906706272?via\%3Dihub
9. Macias-Garcia F, Llovo-Taboada J, Diaz-Lopez M, Baston-Rey I, Dominguez-Munoz JE. High primary antibiotic resistance of Helicobacter pylori strains isolated from dyspeptic patients: a prevalence cross-sectional study in Spain. Helicobacter. 2017;22: e12440. https://onlinelibrary.wiley.com/ doi/epdf/10.1111/hel.12440

10. Alba C, Blanco A, Alarcon T. Antibiotic resistance in Helicobacter pylori. Curr Opin Infect Dis. 2017;30: 489-497. https://journals.lww.com/ co-infectiousdiseases/Fulltext/2017/10000/Antibiotic_resistance_in_Helicobacter_pylori.8.aspx

11. Walduck AK, Raghavan S. Immunity and vaccine development against Helicobacter pylori. In: Kamiya S, Backert S, eds. Helicobacter pylori in Human Diseases. Advances in Experimental Medicine and Biology, vol 1149, Cham.: Springer; 2019. p. 257-275. https://link.springer.com/chapter/10.1007\%2F5584_2019_370

12. Collado MC, Gonzalez A, Gonzalez R, Hernan$\operatorname{dez}$ M, Ferrus MA, Sanz Y. Antimicrobial peptides are among the antagonistic metabolites produced by bifidobacterium against Helicobacter pylori. Int J Antimicrob Agents. 2005; 25:385-391. https://www.sciencedirect.com/science/article/pii/ S0924857905000312?via\%3Dihub

13. Stojilijkovic I, Evavold BD. (2001) Antimicrobial properties of porphyrins. Expert Opin Investig Drugs. 2001; 10:309-320. https://www.tandfonline.com/doi/abs/10.1517/13543784.10.2.309

14. Ohno T, Kita M, Yamaoka Y, Imamura S, Yamamoto T, Mitsufuji S, et al. Antimicrobial activity of essential oils against Helicobacter pylori. Helicobacter. 2003; 8:207-215. https://onlinelibrary. wiley.com/doi/full/10.1046/j.1523-5378.2003.00 146.x?sid=nlm\%3Apubmed

15. Tombola F, Campello S, De Luca L, Ruggiero P, Del Giudice G, Papini E, et al. Plant polyphenols inhibit VacA, a toxin secreted by the gastric pathogen Helicobacter pylori. FEBS Lett. 2003; 543:184-189. https:// febs.onlinelibrary.wiley.com/doi/ full/10.1016/S0014-5793\%2803\%2900443-5?si$\mathrm{d}=\mathrm{nlm} \% 3$ Apubmed 
16. Eurogast Study Group. Epidemiology of, and risk factors for, Helicobacter pylori infection among 3194 asymptomatic subjects in 17 populations. Gut. 1993; 34:1672-1676. https://www.ncbi.nlm. nih.gov/pmc/articles/PMC1374460/

17. Brenner H, Rothenbacher D, Bode G, Adler G. Relation of smoking and alcohol and coffee consumption to active Helicobacter pylori infection: Cross sectional study. Br Med J. 1997; 315:14891492. https://www.ncbi.nlm.nih.gov/pmc/articles/ PMC2127930/

18. Bujanda L. The effects of alcohol consumption upon the gastrointestinal tract. Am J Gastroenterol. 2000; 95:3374-3382. https://insights.ovid. com/pubmed?pmid $=11151864$

19. Brenner H, Bode G, Adler G, Hoffmeister A, Koenig W, Rothenbacher D. Alcohol as a gastric disinfectant? The complex relationship between alcohol consumption and current Helicobacter pylori infection. Epidemiology. 2001; 12:209-214. https:// journals.lww.com/epidem/Fulltext/2001/03000/ Alcohol_as_a_Gastric_Disinfectant__The_Complex.13.aspx

20. Murray LJ, Lane AJ, Harvey IM, Donovan JL, Nair P, Harvey RF. Inverse relationship between alcohol consumption and active Helicobacter pylori infection: The Bristol Helicobacter Project. Am J Gastroenterol. 2002; 97:2750-2755. https://insights. ovid.com/pubmed?pmid=12425543

21. Marimon JM, Bujanda L, Gutierrez-Stampa MA, Cosme A, Arenas JI. In vitro bactericidal effect of wine against Helicobacter pylori. Am J Gastroenterol. 1998; 93:1392. https://insights.ovid.com/ pubmed?pmid $=9707086$

22. Glupczynski Y. Culture of Helicobacter pylori from biopsies and antimicrobial susceptibility testing. In: Megraud F, Lee A, eds. Helicobacter pylori: Techniques for Clinical Diagnosis and Basic Research, Oxford: WB Saunders Company, p. 1732. 1996.

23. Megraud F, Lee A. Helicobacter pylori: Techniques for Clinical Diagnostics and Basic Research. Oxford: WB Saunders Company; 1996.
24. CLSI/NCCLS. Performance Standards for Antimicrobial Susceptibility Testing. Approved Standard M100-S19. Wayne: CLSI; 2009.

25. National Committee for Clinical Laboratory Standards (NCCLS). Development of in vitro Susceptibility Testing Criteria and Quality Control Parameters, 5th Ed. Philadelphia: American Society for Testing of Materials; 2018.

26. Oleastro M, Gerhard M, Lopes AI, Ramalho P, Cabral J, Guerreiro AS, et al. Helicobacter pylori virulence genotypes in Portuguese children and adults with gastroduodenal pathology. Eur J Clin Microbiol Infect Dis. 2003; 22:85-91. https://link. springer.com/article/10.1007/s10096-002-0865-3

27. Tummuru MKR, Cover TL, Blaser MJ. Cloning and expression of a high-molecular-mass major antigen of Helicobacter pylori: Evidence of linkage to cytotoxin production. Infect Immun. 1993; 61:17991809. https://www.ncbi.nlm.nih.gov/pmc/articles/ PMC280768/

28. Atherton JC, Cao P, Peek RM. Mosaicism in the vacuolating cytotoxin alleles of Helicobacter pylori. Association of specific vacA types with cytotoxin production and peptic ulceration. J Biol Chem. 1995; 270:17771-17779. https://www.sciencedirect.com/science/article/pii/ S0021925817480100?via\%3Dihub

29. Roggero JP, Coen S, Archier P, Rocheville-Divorne C. Etude par C.L.H.P. de la reaction glucoside de malvidine-acetaldehyde-compose phenolique. Conn Vigne Vin. 1987; 21:163-168. https://oeno-one.eu/article/view/1283

30. Megraud F, Lehours P. Helicobacter pylori detection and antimicrobial susceptibility testing. Clin Microbiol Rev. 2007; 20:280-322. https://www. ncbi.nlm.nih.gov/pmc/articles/PMC1865594/

31. Ecclissato C, Marchioretto MAM, Mendonça S, Godoy APO, Guersoni RA, Deguer M, et al. Increased primary resistance to recommended antibiotics negatively affects Helicobacter pylori eradication. Helicobacter. 2002; 7:53-59. https:// onlinelibrary.wiley.com/doi/full/10.1046/j.1523-5 378.2002.00056.x?sid=nlm\%3Apubmed 
32. Lee SY, Shin YW, Hahm KB. Phytoceuticals: mighty but ignored weapons against Helicobacter pylori infection. J Dig Dis. 2008; 9:129-139. https:// onlinelibrary.wiley.com/doi/full/10.1111/j.17512980.2008.00334.x

33. Daroch F, Hoeneisen M, Gonzalez CL, Kawaguchi F, Salgado F, Solar H, et al. In vitro antibacterial activity of Chilean red wines against Helicobacter pylori. Microbios. 2001; 104:79-85. https://pubmed.ncbi.nlm.nih.gov/11297014/

34. Just JR, Daeschel MA. Antimicrobial effects of wine on Escherichia coli O157:H7 and Salmonella typhimurium in a model stomach system. J Food Sci. 2003; 68:285-290. https://onlinelibrary. wiley.com/doi/epdf/10.1111/j.1365-2621.2003. tb14154.x

35. Møretrø T, Daeschel MA. Wine is bactericidal to foodborne pathogens. J Food Sci. 2004; 69:M251-257. https://onlinelibrary.wiley.com/doi/epdf/10.1111/j.1365-2621.2004.tb09938.x

36. Friedman M. Antibacterial, antiviral, and antifungal properties of wines and winery byproducts in relation to their flavonoid content. J Agric Food Chem. 2014; 62:6025-6042. https://pubs.acs.org/ doi/10.1021/jf501266s

37. Kamei H, Hashimoto Y, Koide T, Kojima T, Hasegawa S. Anti-tumor of methanol extracts from red and white wines. Cancer Biother Radiopharm. 1998; 13:447-452. https://www.liebertpub.com/doi/10.1089/cbr.1998.13.447?url_ ver $=$ Z39.88-2003\&rfr_id=ori\%3Arid\%3Acrossref. org $\&$ rfr_dat $=$ cr_pub++0pubmed $\&$

38. Belleville J. The French paradox: possible involvement of ethanol in the protective effect against cardiovascular diseases. Nutrition. 2002; 18:173-177.

39. Daglia, M. Polyphenols as antimicrobial agents. Curr Opin Biotechnol. 2012; 23:174-181. https://www.sciencedirect.com/science/article/pii/ S0899900701007213?via\%3Dihub

40. Mahady GB, Pendland SL. Resveratrol inhibits the growth of Helicobacter pylori in vitro. Am J Gastroenterol. 2000; 95:1849. https://insights.ovid. $\mathrm{com} /$ pubmed?pmid= 10926010
41. Wang D, Xu Y, Liu W. Tissue distribution and excretion of resveratrol in rat alter oral administration of Polygonum cuspidatum extract (PCE). Phytomedicine. 2008; 15:859-866. https://www.sciencedirect.com/science/article/pii/ S0944711308000287?via\%3Dihub

42. Orallo F. Trans-resveratrol: a magical elixir of eternal youth?. Curr Med Chem. 2008; 15:1887-1898. https://pubmed.ncbi.nlm.nih.gov/18691046/

43. Mahady GB, Pendland SL, Chadwick LR. Resveratrol and red wine extracts inhibit the growth of CagA + strains of Helicobacter pylori in vitro. Am J Gastroenterol. 2003; 98:1440-1441. https://www. ncbi.nlm.nih.gov/pmc/articles/PMC2860858/

44. Dong W, Zhon Y, Yang Z. Research progress of mechanism of action of resveratrol. Pharmacol Pharm. 2016; 7:170-175. DOI: 10.4236/pp.2016.74022

45. Ghiara P, Marchetti M, Blaser MJ, Tummuru MK, Cover TL, Segal ED, et al. Role of the Helicobacter pylori virulence factors vacuolating cytotoxin, CagA, and urease in a mouse model of disease. Infect Immun. 1995; 63:4154-4160. https://www. ncbi.nlm.nih.gov/pmc/articles/PMC173584/

46. Salama NR, Otto G, Tompkins L, Falkow S. Vacuolating cytotoxin of Helicobacter pylori plays a role during colonization in a mouse model of infection. Infect Immun. 2001; 69:730-736. https:// www.ncbi.nlm.nih.gov/pmc/articles/PMC97945/

47. Hemaiswarya S, Kruthiventi AK, Doble M. Synergism between natural products and antibiotics against infectious disease. Phytomedicine. 2008; 15:639-652. https://www.sciencedirect.com/science/article/pii/S0944711308001104?via\%3Dihub

48. Sung WG, Lee DG. Mechanism of decreased susceptibility for Gram-negative bacteria and synergistic effect with ampicillin of indole-3-carbinol. Biol Pharm Bull. 2008; 31:1798-1801. https:// pubmed.ncbi.nlm.nih.gov/18758080/ 